\title{
ISOTOPIC ANALYSIS AND CYCLING OF DISSOLVED INORGANIC CARBON AT LAKE BIWA, CENTRAL JAPAN
}

\author{
TOSHIO NAKAMURA, ${ }^{1}$ SADAO KOJIMA, ${ }^{2}$ TOMOKO OHTA, ${ }^{1}$ HIROTAKA ODA, ${ }^{1}$ AKIKO \\ IKEDA, ${ }^{1}$ MITSURU OKUNO ${ }^{1} \mathrm{KI}$-ICHIRO YOKOTA ${ }^{3}$ YOSHIHIKO MIZUTANI ${ }^{4}$ and \\ WOLFGANG KRETSCHMER ${ }^{5}$
}

\begin{abstract}
This paper reports on concentrations and carbon isotopic results of dissolved inorganic carbon (DIC) in water samples collected at four locations and from several depths in Lake Biwa, central Japan, covering every season of the year, starting in the spring of 1995. Depth profiles of DIC concentration and DIC $\delta^{13} \mathrm{C}$ showed a strong seasonal pattern, as a result of vertical mixing of the lake water in winter and early spring, or lack of mixing in the other seasons. No seasonal change in DIC $\Delta^{14} \mathrm{C}$ depth profiles was recognizable, mainly owing to the wide scatter of DIC $\Delta^{14} \mathrm{C}$. Values typically ranged from 0.47 to $0.65 \mathrm{mmol} \mathrm{kg}^{-1}$ for DIC concentration, and from -4 to $-8 \%$ and from +10 to $+80 \%$ for DIC $8^{13} \mathrm{C}$ and DIC $\Delta^{14} \mathrm{C}$, respectively, for the Lake Biwa water.
\end{abstract}

\section{INTRODUCTION}

Lacustrine sediments contain a continuous environmental record of the past, and environmental changes from very recent years to a few million years ago have been determined using lake sediment samples (Horie 1984). For example, cored sediment samples up to $1400 \mathrm{~m}$ in length, collected from the northern basin of Lake Biwa, have enabled investigation of paleoenvironmental variations over the last $400 \mathrm{ka}$. By analyses of pollen and diatom assemblages, and $\delta^{13} \mathrm{C}$ and $\mathrm{C} / \mathrm{N}$ ratios of organic components in the cored sediments, glacial and interglacial cycles have been identified for the Lake Biwa region (Fuji 1983, 1986; Nakai 1973, 1986a,b; Meyers, Takemura and Horie 1993).

As an interface between atmosphere and lake sediments, lake water is worth examining, in particular for the study of $\mathrm{CO}_{2}$ exchange between the two carbon reservoirs, atmosphere and sediment. We have observed the recording of a ${ }^{14} \mathrm{C}$ increase in atmospheric $\mathrm{CO}_{2}$, as a consequence of nuclear weapon tests that were conducted in the atmosphere from the late 1950s until the early 1960s, in the annual rings of a Kiso Hinoki cypress tree (Chamaecyparis obtusa) that was collected from Gifu Prefecture, central Japan (Nakamura, Nakai and Ohishi 1987; Nakamura et al. 1992). In addition, we observed the increase in ${ }^{14} \mathrm{C}$ concentration due to artificially produced ${ }^{14} \mathrm{C}$ in organic materials in the bottom sediments of Lake Biwa in Shiga Prefecture (Nakamura et al. 1986; Nakamura, Nakai and Ohishi 1987), Lake Hamana-ko in Shizuoka Prefecture and Horokayanto Lake in Hokkaido Prefecture (Nakamura, Ohishi and Nakai 1993). To conduct carbon isotopic analyses of inorganic carbon (DIC) dissolved in the lake water, we collected water samples from four locations at several depths in Lake Biwa, for every season of the year starting in the spring of 1995 . We discuss here the results of the carbon isotopic analyses of the Lake Biwa water samples.

\section{SITE DESCRIPTION}

Lake Biwa, the most extensive lake in Japan, with a surface area of $674 \mathrm{~km}^{2}$, is located in Shiga Prefecture in the central part of Japan (Fig. 1). The lake measures $63.5 \mathrm{~km}$ from south to north, and 40.2 $\mathrm{km}$ from east to west. It is divided into two basins by a 1.4-km-wide strait in the southern part (Fig. 1). The northern basin constitutes the main lake, with $91.5 \%$ of its surface area, and a water depth of

\footnotetext{
${ }^{1}$ Dating and Materials Research Center, Nagoya University, Chikusa, Nagoya 464-8602 Japan

${ }^{2}$ Radioisotope Research Center, Aichi Medical University, 21, Nagakute-cho, Aichi-gun 480-1195 Japan

${ }^{3}$ Lake Biwa Research Institute, Shiga Prefecture, 1-10 Uchidehama, Otsu 520 Japan

${ }^{4}$ Faculty of Science, Toyama University, 3190, Gofuku, Toyama 930 Japan

${ }^{5}$ Physikalisches Institut, Universität Erlangen-Nürnberg, D-91058 Erlangen, Germany
} 


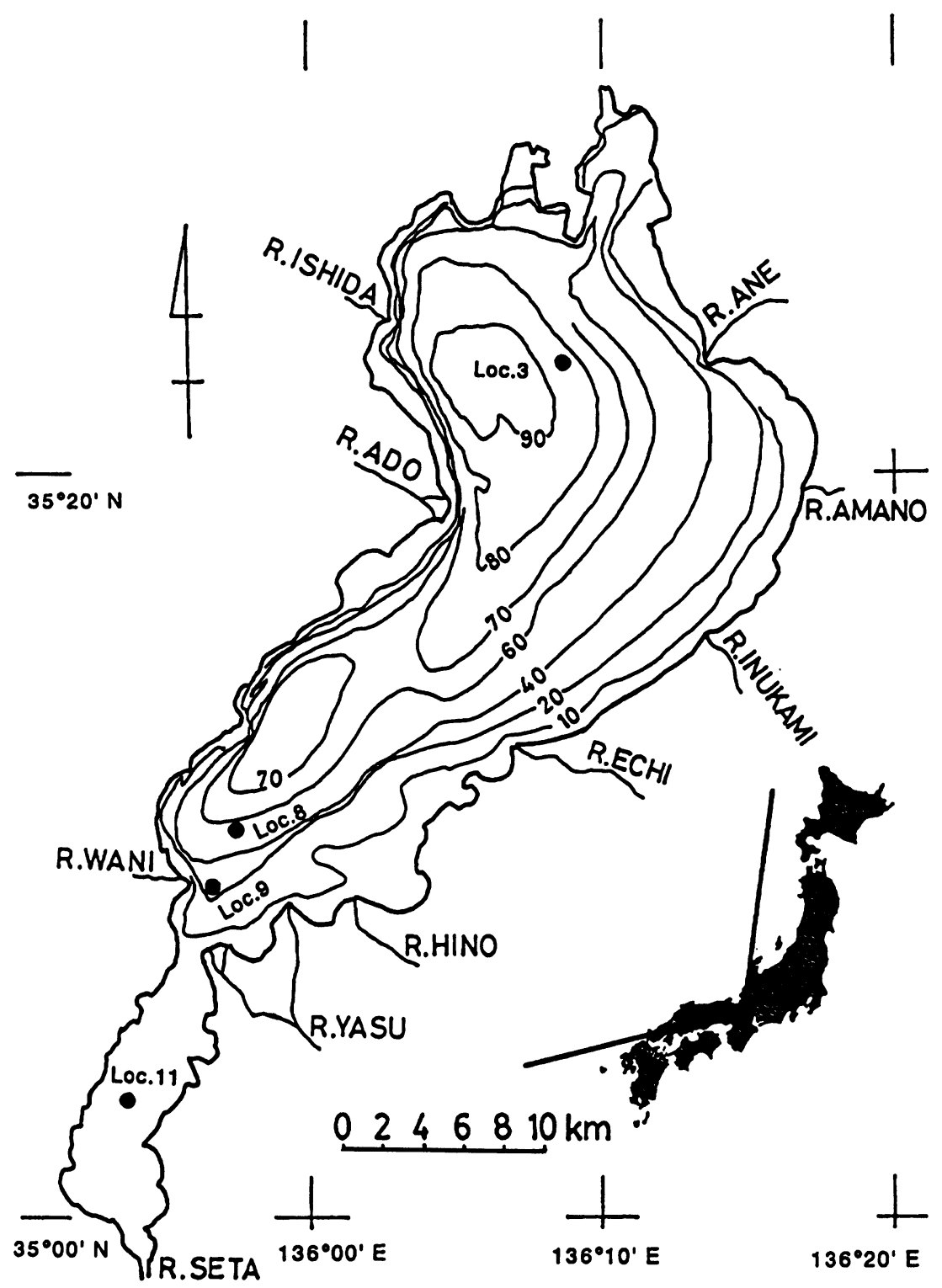

Fig. 1. Locations of water sample collection in Lake Biwa

$70-100 \mathrm{~m}$ in the central area. The maximum depth of $104 \mathrm{~m}$ is found at the west side of the north basin, and the average water depth is $41 \mathrm{~m}$. The southern basin contains only $1 \%$ of the total volume of water in the lake, with a maximum depth of $6 \mathrm{~m}$. The total volume of water in both basins is 2.75 $\times 10^{10} \mathrm{~m}^{3}$. The elevation of the lake surface is $85 \mathrm{~m}$ above sea level. The drainage area of the lake is $3174 \mathrm{~km}^{2}$, extending almost to the borders of Shiga Prefecture.

The circulation of water in the lake has been studied intensively. The surface water circulates counterclockwise in the north part and clockwise in the south part of the northern basin at a speed of 10 $\mathrm{cm} \mathrm{s}^{-1}$ during the lake's thermal stratification period in spring, summer and autumn (Endoh 1986). 
In addition, cooled high-density surface water from the southern basin flows down deep into the northern basin in late winter and early spring, as a dense current. In summer, surface water is heated to a temperature of $c a .30^{\circ} \mathrm{C}$, as shown below in Figure 2, though the deeper water is as cool as $8^{\circ} \mathrm{C}$ at locations 3 and 8 . Thus the lake water stratifies, and the upper water does not mix with the lower water in deeper regions. On the other hand, in winter, the surface water is cooled to produce highdensity water that submerges to, and mixes with, the deeper water. Lake Biwa is an oligotrophic lake, and dissolved oxygen still exists in the bottom waters, even in summer and autumn when the stratification is strongly developed and the deeper water is cut off from the oxygenated surface water.

\section{METHODS}

We collected lake water samples at four locations and several depths in Lake Biwa, from 31 May 1995 until 12 March 1996, using a Rosette multi-water sampler with 24 containers of 5 L capacity (Table 1). Table 1 shows locations and water depths of the four sampling stations. We collected water samples from the Hakken-go ("discovery"), a 36 ton research ship belonging to the Lake Biwa Institute, Shiga Prefecture. The vessel is equipped with a fine-scale profiler that was developed by the Centre for Water Research of the University of West Australia, Nedlands, Western Australia 6009 (Report no. WP 733 RS). The profiler is a field measurement system for water-mixing and biological investigations, and consists of sensors for depth, water temperature, electric conductivity, dissolved oxygen content, $\mathrm{pH}$ and chlorophyll-a content, along with the multi-water sampler. Thus, when we collected water samples, we measured such parameters and recorded them on a personal computer system.

TABLE 1. Concentrations, $\delta^{13} C$ vs. VPDB, $R$ and $\Delta^{14} C$ Values of DIC in Water Samples from Lake Biwa

\begin{tabular}{|c|c|c|c|c|c|c|c|c|}
\hline $\begin{array}{l}\text { Sampling } \\
\text { date } \\
\text { (yr/mo/day) }\end{array}$ & $\begin{array}{l}\text { Sampling } \\
\text { location } \\
\text { (depth:m)* }\end{array}$ & $\begin{array}{l}\text { Sampling } \\
\text { depth } \\
\text { (m) }\end{array}$ & $\begin{array}{c}\text { DIC } \\
\text { concentration } \\
\left(\mathrm{mmol} \mathrm{kg}^{-1}\right)\end{array}$ & $\mathbf{R}$ & $\begin{array}{c}\Delta R / R \\
(\sigma)\end{array}$ & $\begin{array}{l}\text { DIC } \\
\delta^{13} \mathrm{C} \\
(\% 0)\end{array}$ & $\begin{array}{l}\mathrm{DIC} \\
\Delta^{14} \mathrm{C} \\
(\%)\end{array}$ & $\begin{array}{l}\text { St. dev. } \\
\left(\sigma, \Phi_{0}\right)\end{array}$ \\
\hline \multicolumn{9}{|c|}{ Spring samples } \\
\hline $95 / 05 / 31$ & $\begin{array}{l}\text { Loc. } 3 \\
(\mathrm{~d}=88.7)\end{array}$ & $\begin{array}{r}0 \\
10 \\
20 \\
30 \\
40 \\
60 \\
80 \\
88\end{array}$ & $\begin{array}{l}0.53 \\
0.55 \\
0.57 \\
0.58 \\
0.61 \\
0.57 \\
0.62 \\
0.59\end{array}$ & $\begin{array}{l}1.035 \\
1.075 \\
1.027 \\
1.015 \\
1.074 \\
1.098 \\
1.055 \\
1.044\end{array}$ & $\begin{array}{l}0.007 \\
0.009 \\
0.010 \\
0.010 \\
0.008 \\
0.009 \\
0.007 \\
0.008\end{array}$ & $\begin{array}{l}-4.4 \\
-4.6 \\
-5.5 \\
-5.7 \\
-6.4 \\
-6.3 \\
-6.9 \\
-6.8\end{array}$ & $\begin{array}{l}35 \\
75 \\
27 \\
15 \\
74 \\
98 \\
55 \\
44\end{array}$ & $\begin{array}{r}7 \\
10 \\
10 \\
10 \\
8 \\
10 \\
7 \\
8\end{array}$ \\
\hline $95 / 05 / 31$ & $\begin{array}{l}\text { Loc. } 8 \\
(d=51.3)\end{array}$ & $\begin{array}{r}0 \\
10 \\
20 \\
30 \\
40 \\
45\end{array}$ & $\begin{array}{l}0.47 \\
0.52 \\
0.56 \\
0.56 \\
0.58 \\
0.60\end{array}$ & $\begin{array}{l}1.050 \\
1.052 \\
1.009 \\
1.044 \\
1.063 \\
1.045\end{array}$ & $\begin{array}{l}0.008 \\
0.007 \\
0.007 \\
0.008 \\
0.008 \\
0.007\end{array}$ & $\begin{array}{l}-4.1 \\
-4.4 \\
-5.7 \\
-5.8 \\
-6.2 \\
-6.9\end{array}$ & $\begin{array}{r}50 \\
52 \\
9 \\
44 \\
63 \\
45\end{array}$ & $\begin{array}{l}8 \\
8 \\
7 \\
8 \\
8 \\
8\end{array}$ \\
\hline $95 / 05 / 31$ & $\begin{array}{l}\text { Loc.11 } \\
(\mathrm{d}=3.7)\end{array}$ & 0 & 0.55 & 1.058 & 0.008 & -4.5 & 58 & 8 \\
\hline \multicolumn{9}{|c|}{ Summer samples } \\
\hline $95 / 08 / 03$ & $\begin{array}{l}\text { Loc. } 3 \\
(\mathrm{~d}=88.7)\end{array}$ & $\begin{array}{r}0 \\
5 \\
12 \\
40 \\
80\end{array}$ & $\begin{array}{l}0.48 \\
0.47 \\
0.55 \\
0.62 \\
0.62\end{array}$ & $\begin{array}{l}1.042 \\
1.043 \\
1.016 \\
1.059 \\
1.041\end{array}$ & $\begin{array}{l}0.009 \\
0.008 \\
0.008 \\
0.012 \\
0.008\end{array}$ & $\begin{array}{l}-4.0 \\
-3.8 \\
-4.8 \\
-7.2 \\
-7.3\end{array}$ & $\begin{array}{l}42 \\
43 \\
16 \\
59 \\
41\end{array}$ & $\begin{array}{r}9 \\
8 \\
8 \\
13 \\
8\end{array}$ \\
\hline
\end{tabular}


TABLE 1. Concentrations, $\delta^{13} \mathrm{C}$ vs. VPDB, $\mathrm{R}$ and $\Delta^{14} \mathrm{C}$ Values of DIC in Water Samples from Lake Biwa (Continued)

\begin{tabular}{|c|c|c|c|c|c|c|c|c|}
\hline $\begin{array}{l}\text { Sampling } \\
\text { date } \\
\text { (yr/mo/day) }\end{array}$ & $\begin{array}{l}\text { Sampling } \\
\text { location } \\
\text { (depth:m)* }\end{array}$ & $\begin{array}{l}\text { Sampling } \\
\text { depth } \\
\text { (m) }\end{array}$ & $\begin{array}{c}\text { DIC } \\
\text { concentration } \\
\left(\mathrm{mmol} \mathrm{kg}^{-1}\right) \\
\end{array}$ & $\mathbf{R}$ & $\begin{array}{c}\Delta R / R \\
(\sigma)\end{array}$ & $\begin{array}{l}\text { DIC } \\
\delta^{13} \mathrm{C} \\
(\% 0) \\
\end{array}$ & $\begin{array}{l}\text { DIC } \\
\Delta^{14} \mathrm{C} \\
(\% 0) \\
\end{array}$ & $\begin{array}{l}\text { St. dev. } \\
\left(\sigma, \%_{0}\right)\end{array}$ \\
\hline $95 / 08 / 03$ & $\begin{array}{l}\text { Loc.8 } \\
(d=51.3)\end{array}$ & $\begin{array}{r}5 \\
12 \\
25 \\
40\end{array}$ & $\begin{array}{l}0.49 \\
0.58 \\
0.60 \\
0.62\end{array}$ & $\begin{array}{l}1.023 \\
1.045 \\
1.057 \\
1.046\end{array}$ & $\begin{array}{l}0.008 \\
0.008 \\
0.008 \\
0.008\end{array}$ & $\begin{array}{l}-4.2 \\
-6.1 \\
-6.5 \\
-7.2\end{array}$ & $\begin{array}{l}23 \\
45 \\
57 \\
46\end{array}$ & $\begin{array}{l}8 \\
8 \\
8 \\
8\end{array}$ \\
\hline $95 / 08 / 03$ & $\begin{array}{l}\text { Loc.11 } \\
(d=3.7)\end{array}$ & 2 & 0.52 & 1.025 & 0.007 & -5.4 & 25 & 8 \\
\hline \multicolumn{9}{|c|}{ Autumn samples } \\
\hline $95 / 10 / 30$ & $\begin{array}{l}\text { Loc.3 } \\
(d=88.7)\end{array}$ & $\begin{array}{r}0 \\
5 \\
12 \\
40 \\
80\end{array}$ & $\begin{array}{l}0.52 \\
0.54 \\
0.55 \\
0.58 \\
0.66\end{array}$ & $\begin{array}{l}1.040 \\
1.058 \\
1.031 \\
1.054 \\
1.063\end{array}$ & $\begin{array}{l}0.007 \\
0.008 \\
0.007 \\
0.009 \\
0.010\end{array}$ & $\begin{array}{l}-4.1 \\
-4.1 \\
-4.2 \\
-7.1 \\
-8.5\end{array}$ & $\begin{array}{l}40 \\
58 \\
31 \\
54 \\
63\end{array}$ & $\begin{array}{r}7 \\
8 \\
8 \\
9 \\
11\end{array}$ \\
\hline $95 / 10 / 30$ & $\begin{array}{l}\text { Loc.8 } \\
(d=51.3)\end{array}$ & $\begin{array}{r}0 \\
5 \\
12 \\
25 \\
40\end{array}$ & $\begin{array}{l}0.54 \\
0.53 \\
0.53 \\
0.56 \\
0.63\end{array}$ & $\begin{array}{l}1.030 \\
1.032 \\
1.056 \\
1.040 \\
1.088\end{array}$ & $\begin{array}{l}0.007 \\
0.010 \\
0.008 \\
0.008 \\
0.013\end{array}$ & $\begin{array}{l}-4.0 \\
-4.0 \\
-4.1 \\
-4.4 \\
-7.2\end{array}$ & $\begin{array}{l}30 \\
32 \\
56 \\
40 \\
88\end{array}$ & $\begin{array}{r}7 \\
10 \\
8 \\
8 \\
15\end{array}$ \\
\hline $95 / 10 / 30$ & $\begin{array}{l}\text { Loc.11 } \\
(\mathrm{d}=3.7)\end{array}$ & $\begin{array}{l}2 \\
2\end{array}$ & $\begin{array}{l}0.56 \\
0.57\end{array}$ & $\begin{array}{l}1.008 \\
1.042\end{array}$ & $\begin{array}{l}0.007 \\
0.011\end{array}$ & $\begin{array}{l}-4.6 \\
-4.7\end{array}$ & $\begin{array}{r}8 \\
42\end{array}$ & $\begin{array}{r}8 \\
11\end{array}$ \\
\hline \multicolumn{9}{|c|}{ Winter samples } \\
\hline $96 / 02 / 07$ & $\begin{array}{l}\text { Loc. } 8 \\
(d=51.3)\end{array}$ & $\begin{array}{r}2 \\
12 \\
25 \\
45\end{array}$ & $\begin{array}{l}0.58 \\
0.56 \\
0.56 \\
0.55\end{array}$ & $\begin{array}{l}1.029 \\
0.984 \\
1.053 \\
1.054\end{array}$ & $\begin{array}{l}0.007 \\
0.009 \\
0.007 \\
0.007\end{array}$ & $\begin{array}{l}-5.7 \\
-6.0 \\
-5.8 \\
-5.7\end{array}$ & $\begin{array}{r}29 \\
-16 \\
53 \\
54\end{array}$ & $\begin{array}{l}7 \\
9 \\
8 \\
8\end{array}$ \\
\hline $96 / 02 / 07$ & $\begin{array}{l}\text { Loc. } 9 \\
(\mathrm{~d}=23)\end{array}$ & $\begin{array}{r}2 \\
20\end{array}$ & $\begin{array}{l}0.57 \\
0.58\end{array}$ & $\begin{array}{l}1.026 \\
1.032\end{array}$ & $\begin{array}{l}0.010 \\
0.009\end{array}$ & $\begin{array}{l}-5.7 \\
-5.8\end{array}$ & $\begin{array}{l}26 \\
32\end{array}$ & $\begin{array}{r}10 \\
9\end{array}$ \\
\hline $96 / 02 / 07$ & $\begin{array}{l}\text { Loc.11 } \\
(\mathrm{d}=3.7)\end{array}$ & 2 & 0.55 & 1.043 & 0.008 & -4.4 & 43 & 9 \\
\hline $96 / 03 / 12$ & $\begin{array}{l}\text { Loc.3 } \\
(\mathrm{d}=88.7)\end{array}$ & $\begin{array}{r}2 \\
5 \\
12 \\
40 \\
80\end{array}$ & $\begin{array}{l}0.60 \\
0.59 \\
0.59 \\
0.59 \\
0.59\end{array}$ & $\begin{array}{l}1.039 \\
1.065 \\
1.042 \\
1.050 \\
1.051\end{array}$ & $\begin{array}{l}0.008 \\
0.008 \\
0.008 \\
0.007 \\
0.010\end{array}$ & $\begin{array}{l}-5.7 \\
-5.6 \\
-5.6 \\
-5.7 \\
-5.7\end{array}$ & $\begin{array}{l}39 \\
65 \\
42 \\
50 \\
51\end{array}$ & $\begin{array}{r}8 \\
8 \\
8 \\
8 \\
11\end{array}$ \\
\hline $96 / 03 / 12$ & $\begin{array}{l}\text { Loc.8 } \\
(\mathrm{d}=51.3)\end{array}$ & $\begin{array}{r}2 \\
5 \\
12 \\
25 \\
45\end{array}$ & $\begin{array}{l}0.60 \\
0.60 \\
0.59 \\
0.59 \\
0.60\end{array}$ & $\begin{array}{l}1.046 \\
1.037 \\
1.053 \\
1.040 \\
1.038\end{array}$ & $\begin{array}{l}0.007 \\
0.008 \\
0.009 \\
0.007 \\
0.013\end{array}$ & $\begin{array}{l}-5.3 \\
-5.5 \\
-5.4 \\
-5.3 \\
-5.5\end{array}$ & $\begin{array}{l}46 \\
37 \\
53 \\
40 \\
38\end{array}$ & $\begin{array}{r}8 \\
9 \\
9 \\
8 \\
14\end{array}$ \\
\hline $96 / 03 / 12$ & $\begin{array}{l}\text { Loc.11 } \\
(\mathrm{d}=3.7)\end{array}$ & 2 & 0.57 & 1.089 & 0.007 & -4.5 & 89 & 8 \\
\hline
\end{tabular}

We transferred ca. $300 \mathrm{~mL}$ of each water sample into a $300 \mathrm{~mL}$ Erlenmeyer flask, added $10 \mathrm{~mL}$ of ammoniacal concentrated $\mathrm{SrCl}_{2}$ solution, and tightly sealed the flask using Apiezon grease and adhesive tape before bringing it back to the laboratory. We recovered the DIC fraction from the 
water samples, using to a method similar to that developed originally by Mizutani et al. (1992) and Mizutani and Yamamoto (1993).

The DIC from water samples in the flask was already deposited in the form of $\mathrm{SrCO}_{3}$ by the time the samples were brought back to the laboratory. In a $\mathrm{CO}_{2}$-free atmosphere, produced in a glove box by exposing the air to alkali materials for several hours (ca. $300 \mathrm{cc}$ of Ascarite-II, sodium hydroxide on a nonfibrous silicate carrier, from Thomas Scientific, USA), we removed a DIC-free portion of the water sample in the flask by decantation, and placed a $10 \mathrm{~mL}$ sample bottle with $5 \mathrm{~mL} \mathrm{H}_{3} \mathrm{PO}_{4}$ in the flat-bottomed flask. Then we evacuated the flask and sealed it, using a vacuum stopcock. The $\mathrm{SrCO}_{3}$ in the flask was decomposed to produce $\mathrm{CO}_{2}$ by turning over the $\mathrm{H}_{3} \mathrm{PO}_{4}$ bottle. To ensure complete $\mathrm{SrCO}_{3}$ decomposition, the flask was left overnight. On the following day, we separated the produced $\mathrm{CO}_{2}$ cryogenically by using a liquid $\mathrm{N}_{2}$ and ethanol mixture at $\mathrm{ca} .-100^{\circ} \mathrm{C}$ for trapping water, and liquid $\mathrm{N}_{2}$ for $\mathrm{CO}_{2}$. We measured the yield of $\mathrm{CO}_{2}$ by expanding it to a known volume with a pressure transducer. Then we divided the $\mathrm{CO}_{2}$ into two parts and stored them in Pyrex ${ }^{\circledR}$ ampoules of $6 \mathrm{~mm}$ $\mathrm{OD}$, for further carbon isotopic analyses.

\section{Graphite Target Preparation and ${ }^{14} \mathrm{C}$ Measurement}

We produced a graphite target by reducing enough of the DIC-generated $\mathrm{CO}_{2}$ to contain $c a .1 \mathrm{mg}$ of carbon, with hydrogen on iron powder at $650^{\circ} \mathrm{C}$ (Kitagawa et al. 1993). We measured the ${ }^{14} \mathrm{C} /{ }^{13} \mathrm{C}$ ratio of the sample graphite in a GIC tandetron AMS at Nagoya University (Nakamura et al. 1985, 1992), using a NIST oxalic acid ${ }^{14} \mathrm{C}$ standard (HOxI, SRM-4990). We can routinely measure ${ }^{14} \mathrm{C}$ concentrations to a precision of $\pm 0.8-1.0 \%$ for modern samples of $>1 \mathrm{mg}$ carbon. We also measured $\delta^{13} C_{\text {PDB }}$ values of DIC-generated $\mathrm{CO}_{2}$ with a precision of $\pm 0.1 \%$ in a triple collector mass spectrometer (MAT ${ }^{\mathrm{TM}}$ 252, Finnigan Corporation).

We give ${ }^{14} \mathrm{C}$ concentrations by $\mathrm{R}$ and $\Delta{ }^{14} \mathrm{C}$ values that are derived by modifying equations originally developed by Stuiver and Polach (1977)

$$
R=R_{\text {meas }} / 0.95 \frac{1+\delta^{13} C_{s a}}{1+\delta^{13} C_{s t}} \frac{1-2\left(0.025+\delta^{13} C_{s a}\right)}{1-2\left(0.019+\delta^{13} C_{s t}\right)} e^{-\lambda(T-1950)},
$$

where $R_{\text {meas }}$ indicates the sample ${ }^{14} \mathrm{C} /{ }^{13} \mathrm{C}$ ratio divided by the ratio for the HOxI to be measured with our Tandetron AMS (i.e., $\left({ }^{14} \mathrm{C} /{ }^{13} \mathrm{C}\right)_{\mathrm{sa}} /\left({ }^{14} \mathrm{C} /{ }^{13} \mathrm{C}\right)$ st; subscripts "sa" and "st" indicate sample and standard), $\delta^{13} \mathrm{C}$ is the stable isotope ratio of carbon, and 0.019 refers to the accepted $\delta^{13} \mathrm{C}_{\mathrm{st}}$ value $(-19 \%)$ of HOxI. $\delta^{13} C_{s t}$ was not measured for each target but was assumed constant at $-19 \%$. T denotes the year of water-sample collection. By using the calculated value for $R, \Delta{ }^{14} \mathrm{C}$ is given as

$$
\Delta{ }^{14} \mathrm{C}=\mathrm{R}-1 \quad\left(\times 10^{3} \% 0\right) \text {. }
$$

\section{RESULTS AND DISCUSSION}

\section{Reproducibility of DIC Extraction}

Though the DIC extraction procedure applied for this study requires at least 2 days to process one sample, we can treat a number of samples together without difficulty. In addition, we can evaluate the DIC content with a reasonable precision of $c a . \pm 0.01 \mathrm{mmol} \mathrm{kg}^{-1}$, as indicated by duplicate runs.

We have conducted duplicate DIC extractions and carbon isotopic analyses for a water sample collected at location 11 on 30 October 1995 (Table 1). The DIC concentration and DIC $\delta^{13} \mathrm{C}$ were 
almost identical for the two independent runs. The differences were $0.01 \mathrm{mmol} \mathrm{kg}^{-1}$ and $0.1 \%$ for DIC concentration and DIC $\delta^{13} \mathrm{C}$ values between the two runs. This suggests that the reproducibility of the DIC separation is good and the carbon stable isotope ratio is not affected by the procedure. The DIC $\Delta^{14} \mathrm{C}$ values showed a larger difference than $1 \sigma$ error between the two runs, but were consistent within $2 \sigma$. We plan to conduct more duplicate runs to determine the exact precisions of DIC concentration, DIC $\delta^{13} \mathrm{C}$ and DIC $\Delta^{14} \mathrm{C}$ measurements for the DIC extraction procedures.

\section{Depth Profiles of Water Temperature, Dissolved Oxygen and DIC Concentrations}

Figure 2 shows the lake water temperature profile. In summer and autumn (95/05/31, 95/08/03 and $95 / 10 / 30$ ) the water temperature was higher for the upper waters and lower for the lower waters, and thus the lake waters stratified without any vertical mixing. On the other hand, in winter and early spring the water temperature was almost constant $\left(7^{\circ} \mathrm{C}\right)$ independent of water depth, and thus the lake water mixed very well vertically.

The dissolved oxygen content ranged from 4.8 to $10.3 \mathrm{mg} \mathrm{L}^{-1}$. We observed the minimum value of $4.8 \mathrm{mg} \mathrm{L}^{-1}$ for the bottom water at location 3 on 30 October 1995, when a stratified water column still existed. On the other hand, we observed an almost constant value of $8.3-8.9 \mathrm{mg} \mathrm{L}^{-1}$ at location 3 , independent of depth, on 7 February 1996, when vertical mixing was complete. Thus we noticed that dissolved oxygen was still abundant in the bottom waters even when the water column was stratified.

Table 1 and Figure 3 show the DIC concentration against water depth for locations 3 and 8 . DIC concentration ranged from 0.47 to $0.66 \mathrm{mmol} \mathrm{kg}^{-1}$, and showed a strong seasonal dependence. In winter and early spring (96/02/07 and 96/03/12), vertical mixing of lake water was very active and the DIC concentration was almost constant $\left(0.55-0.6 \mathrm{mmol} \mathrm{kg}^{-1}\right)$, independent of depth. On the other hand, the DIC concentration was fully dependent on depth in late spring, summer, and autumn (95/05/31, $95 / 08 / 03$ and $95 / 10 / 30$ ), when the vertical mixing was not strong or was inactive, i.e., the DIC concentration was higher at the bottom $\left(0.6-0.66 \mathrm{mmol} \mathrm{kg}^{-1}\right)$ than at the top $(0.47-0.54 \mathrm{mmol} \mathrm{kg}-1)$ of the water column. The higher DIC concentration at the lake bottom in the highly stratified period likely was caused by the addition of $\mathrm{CO}_{2}$ that was produced by disintegration of organic materials contained in the surface sediments, and by non-mixing of the deeper waters with the lower DIC concentration upper waters.

\section{Depth Profile of Carbon Isotope Ratios}

Table 1 and Figure 3 show the carbon stable isotope ratio $\delta^{13} \mathrm{C}$ of the DIC fractions against water depth for locations 3 and 8 . The depth profile of the DIC $\delta^{13} \mathrm{C}$ shows a strong seasonal dependence. The DIC $\delta^{13} \mathrm{C}$ was almost constant $(-6.5 \%)$ independent of the water depth, as a result of strong vertical mixing in winter and early spring. On the other hand, surface waters showed high values of DIC $\delta^{13} \mathrm{C}(-4 \%)$ and bottom waters had low values of DIC $\delta^{13} \mathrm{C}(-7$ to $-8.5 \%)$, as the result of columnar stratification from late spring to autumn.

The $\mathrm{pH}$ values of lake water observed on water-sampling days were normally $>7$ and $<8.5$, except for a value of 9.5 for water from the surface to $10 \mathrm{~m}$ deep on 3 August 1995 at locations 3 and 8 . In late winter and early spring, when strong vertical mixing was achieved, the $\mathrm{pH}$ value was $c a .8 .5$, independent of the water depth. Thus the DIC in Lake Biwa water existed mainly in the form of $\mathrm{HCO}_{3}^{-}$. The DIC $\delta^{13} \mathrm{C}$ values were relatively high $(-4$ to $-8.5 \%)$, indicating that the DIC was not affected strongly by $\mathrm{CO}_{2}$ generated by disintegration of organic materials in the surface lake sediments (the $\delta^{13} \mathrm{C}$ value is typically $-25 \%$ for the organic materials in the sediments). The DIC $\delta^{13} \mathrm{C}$ 


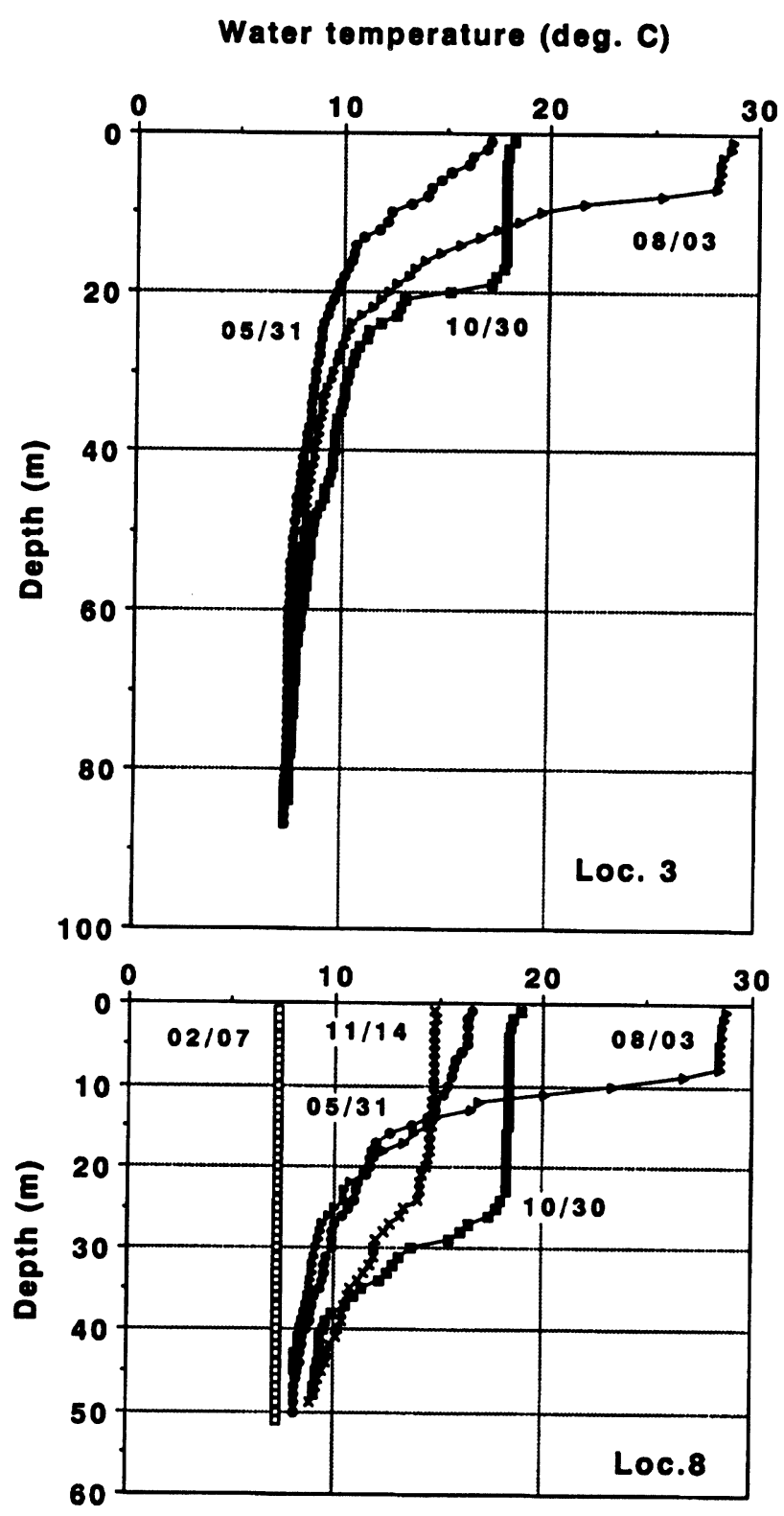

Fig. 2. Vertical profile of lake water temperature at locations 3 (above) and 8 (below). Temperature measurement dates: $\bullet=31$ May 1995; $\Delta=3$ August 1995; = 30 October 1995; $x=14$ November 1995; $\square=7$ February 1996.

for underground water normally shows much lower values $(-15 \%$ to $-20 \%)$ as a consequence of additional $\mathrm{CO}_{2}$ originating in sedimentary organic materials that existed along the path of underground water (Mizutani et al. 1992; Mizutani and Yamamoto 1993). The $\mathrm{CO}_{2}$ exchange between atmosphere and lake water is also important (the $\delta^{13} \mathrm{C}$ value is typically $-7 \%$ for atmospheric $\mathrm{CO}_{2}$ (Keeling 1958)). 

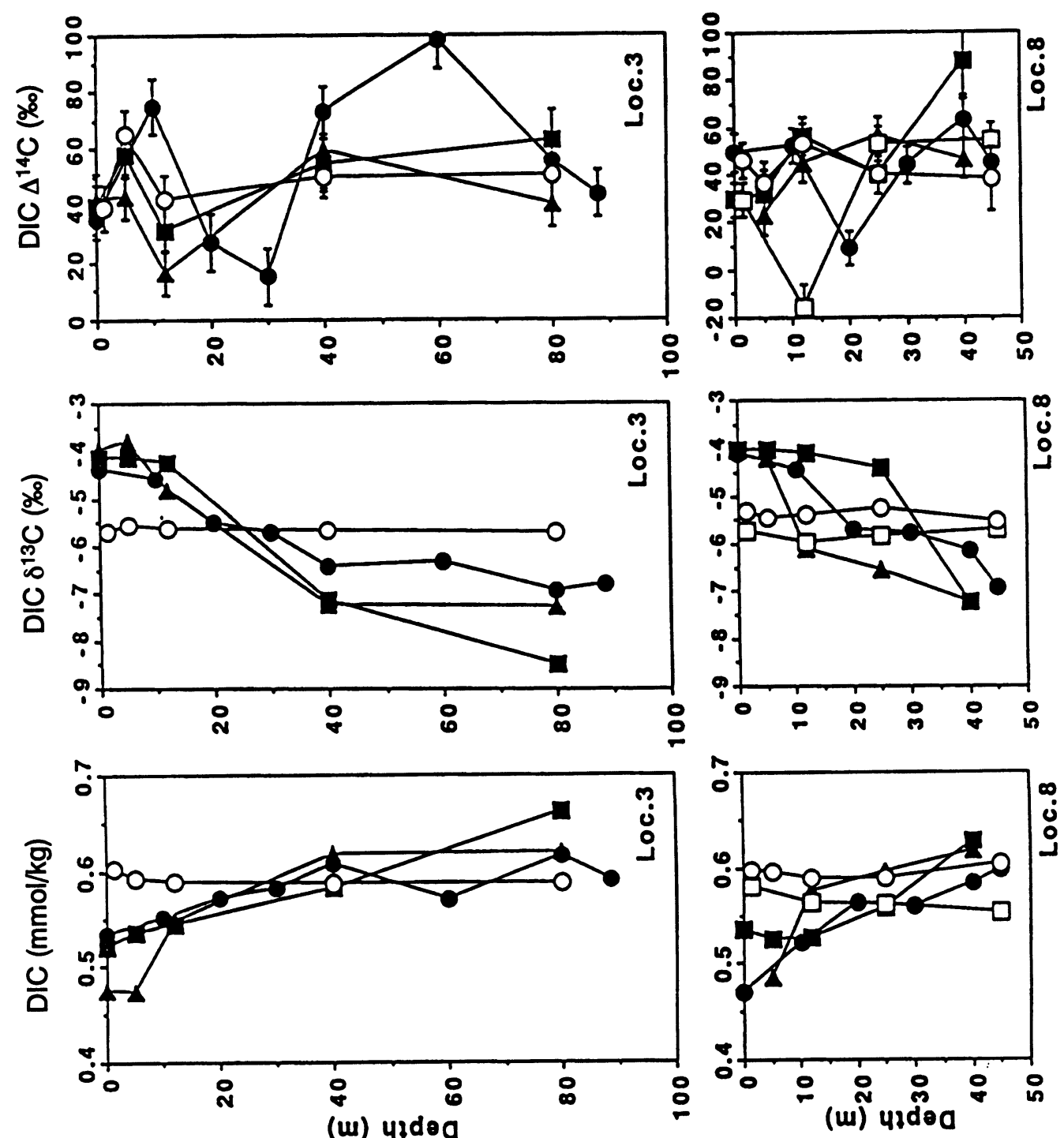

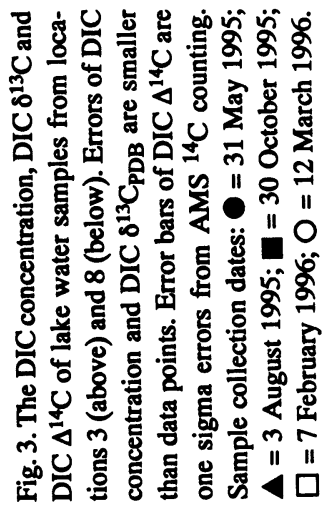


Table 1 and Figure 3 show the ${ }^{14} \mathrm{C}$ concentrations for the DIC fractions, denoted as $\mathrm{R}$ as well as $\Delta \Delta^{14} \mathrm{C}$, defined in Equations 1 and 2. All of the DIC $\Delta^{14} \mathrm{C}$ values were positive except for one sample $(-16 \%)$. This suggests that the DIC fraction in the lake water was still affected by thermonuclear bomb-produced ${ }^{14} \mathrm{C}$ in the atmosphere and on the ground, just as the atmospheric $\mathrm{CO}_{2}$ was. The DIC $\Delta{ }^{14} \mathrm{C}$ did not show a clear depth dependence, owing to rather large $1 \sigma$ errors. However, we found a weak trend wherein the DIC $\Delta^{14} \mathrm{C}$ was relatively higher in the deeper part of the water column than in the upper part (Fig. 3). The DIC $\Delta^{14} \mathrm{C}$ values for bottom water samples were relatively higher (4090\%o) than those for surface water (30-50\%o) in the season of well-stratified water columns, but converged to a smaller range $(40-50 \%)$ in the seasons with strong mixing, although the trend was not clear owing to a wide scatter of data points, as well as rather large $1 \sigma$ errors. Compared with the remarkable dependence of DIC $\delta^{13} \mathrm{C}$ on water depth in late spring, summer and early winter, DIC $\Delta{ }^{14} \mathrm{C}$ showed no clear dependence on water depth, because the $\mathrm{CO}_{2}$ generated from the sediment surface was depleted in ${ }^{13} \mathrm{C}$ but not in ${ }^{14} \mathrm{C}$, when compared with lake water DIC. Temporal variations of $\Delta^{14} \mathrm{C}$ values for atmospheric $\mathrm{CO}_{2}$, DIC fractions in lake water and organic materials in the lake sediment, should be more complicated than the variations of their $\delta^{13} \mathrm{C}$ values, owing to the ${ }^{14} \mathrm{C}$ production by nuclear weapon tests in the early 1960 s.

\section{Seasonal Variations of Carbon Isotope Ratios}

Figure 4 shows seasonal variations of DIC concentration, DIC $\delta^{13} \mathrm{C}$ and DIC $\Delta^{14} \mathrm{C}$ for the uppermost and lowermost lake water samples. Figure 4 also shows the values of these three chemical variables averaged for the full water column. To evaluate the average values, the values at each depth were weighted by the length of the water column that each datum covers, i.e., the length between the central depths of two successive sampling horizons. For example, when we have measured variables at four horizons, then the weight of the uppermost values of the variables is the length between the surface and the middle of the first and the second horizons, the weight of the second is the one between the middle of the first and the second and the middle of the second and the third horizons, and so forth. The weight of the lowermost values is the one between the middle of the third and the forth horizons and the bottom of the water column. We divided the weights by the water column length to normalize them. Since the depth profiles of DIC concentrations and DIC $\delta^{13} \mathrm{C}$ are monotonous (but not those of DIC $\Delta^{14} \mathrm{C}$ ), we can obtain a brief tendency of these variables by the simplified average.

The DIC concentrations for the uppermost water samples were lower during the period of water stratification than during the period of vertical mixing. The DIC concentrations for the lowermost water samples showed the opposite seasonal trend. The wide scatter of DIC concentrations observed during the period of water stratification converged to $0.6 \mathrm{mmol} \mathrm{kg}^{-1}$ when vertical mixing was perfectly complete. We can also see that the averaged values of DIC concentration were almost constant $\left(0.56-0.60 \mathrm{mmol} \mathrm{kg}^{-1}\right)$ independent of season. It seems that the total amount of DIC contained in the water column extending from surface water to bottom water does not change seasonally.

We observed a similar trend for DIC $\delta^{13} \mathrm{C}$ variations, though the polarity was reversed because the $\mathrm{CO}_{2}$ generated from the lake bottom sediments was depleted in ${ }^{13} \mathrm{C}$, i.e., such $\mathrm{CO}_{2}$ gave lower values of DIC $\delta^{13} \mathrm{C}$ (the $\delta^{13} \mathrm{C}$ value is typically $-25 \%$ for organic materials in the sediments). In addition, when phytoplanktons incorporate carbon from surface water through photosynthesis, ${ }^{12} \mathrm{C}$ is fixed more preferentially than ${ }^{13} \mathrm{C}$, yielding a ${ }^{13} \mathrm{C} /{ }^{12} \mathrm{C}$ ratio in planktons $c a$. $20 \%$ lower than that of DIC. The planktons soon deposit on the lake bottom and are oxidized to $\mathrm{CO}_{2}$. Thus ${ }^{12} \mathrm{C}$ of DIC is preferentially transferred from upper to deeper water by biogenic activities. The DIC $\delta^{13} \mathrm{C}$ values averaged over the water column ranged from -5.3 to $-6.6 \%$, almost independent of season. 

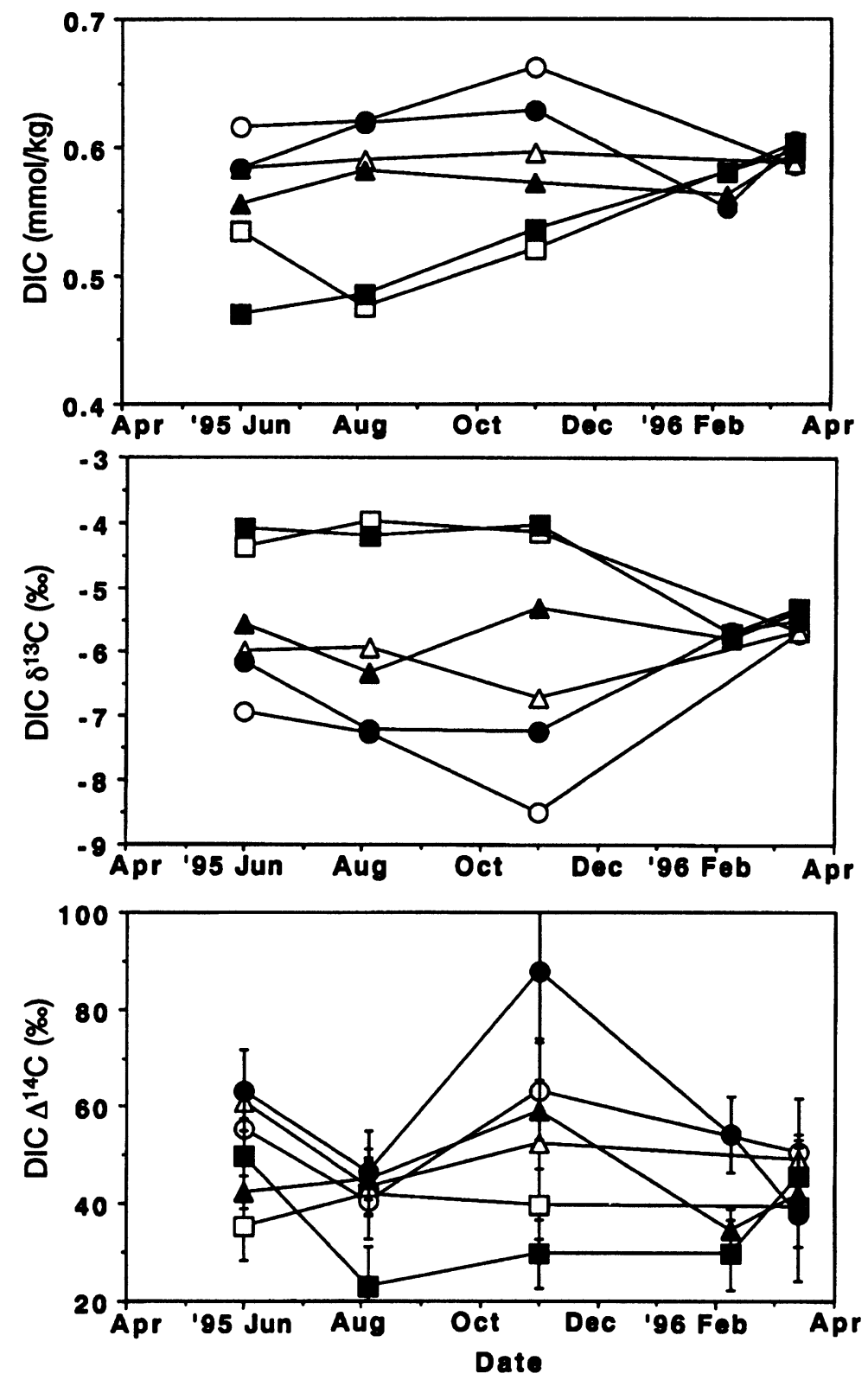

Fig. 4. Seasonal variations of the DIC concentration, DIC $8^{13} \mathrm{C}$ and DIC $\Delta^{14} \mathrm{C}$ for uppermost (up) and lowermost (low) water samples from locations 3 and 8, and averaged values (avg) for the water column. Errors are the same as in Fig. 3. Symbols: $\square=u p$ at loc. 3; $O=$ low at loc. 3; $\Delta=$ avg at loc. $3 ; \square=u p$ at loc. $8 ; O=$ low at loc. $8 ; \Delta=a v g$ at loc. 8 .

The seasonal variations in DIC $\Delta{ }^{14} \mathrm{C}$ for upper and lower water samples, and of DIC $\Delta{ }^{14} \mathrm{C}$ averaged over the water column, were not definitive because of the wide scatter of data points. However, we found weak trends, wherein $\Delta^{14} \mathrm{C}$ values were higher for the bottom DIC than for the surface DIC when the water column was stratified, and DIC $\Delta{ }^{14} \mathrm{C}$ converged to a value of $40-50 \%$ when vertical 
mixing was established. We propose that the higher DIC $\Delta^{14} \mathrm{C}$ for bottom water than for upper water samples is caused by $\mathrm{CO}_{2}$ generated from surface sedimentary organic materials with higher $\Delta^{14} \mathrm{C}$ that were deposited in the last several decades when $\Delta^{14} \mathrm{C}$ values of atmospheric $\mathrm{CO}_{2}$ were much higher than the present values. To test this hypothesis, we are planing to conduct carbon isotopic analyses of the DIC fraction of pore water as well as organic materials from surface sediments of Lake Biwa.

The values of DIC concentration, DIC $\delta^{13} \mathrm{C}$ and DIC $\Delta^{14} \mathrm{C}$ averaged for the water column were almost constant, independent of season (Fig. 4). This suggests that the total amount of DIC contained in the water column and its carbon isotopic composition do not change greatly throughout the year, though the values of three chemical variables can change considerably, depending on the depth of water mass as well as water stratification or non-stratification.

\section{ConCLusion}

We have collected more than 50 water samples from Lake Biwa, from different depths at four locations, covering four seasons of one year from the spring of 1995, and analyzed their DIC concentration, DIC $\delta^{13} \mathrm{C}$ and DIC $\Delta^{14} \mathrm{C}$ values. The results are summarized as follows:

1. Our DIC extraction method using a $\mathrm{CO}_{2}$-free glove box and a $\mathrm{CO}_{2}$-purification vacuum line is reliable and easy to carry out, though the extraction requires at least 2 days.

2. The values of DIC concentration, DIC $\delta^{13} \mathrm{C}$ and DIC $\Delta^{14} \mathrm{C}$ ranged typically from 0.47 to 0.65 $\mathrm{mmol} \mathrm{kg}-1,-4$ to $-8 \%$, and +10 to $+80 \%$, respectively, for the Lake Biwa water.

3. Depth profiles of DIC concentrations and DIC $\delta^{13} \mathrm{C}$ values showed a strong seasonal dependence, as the result of vertical mixing or non-mixing of the lake water in the winter and summer seasons, respectively.

4. Based on the depth profiles and seasonal variations of DIC concentration, DIC $\delta^{13} \mathrm{C}$ and DIC $\Delta{ }^{14} \mathrm{C}$ values, we can propose two main carbon sources of DIC: one is the $\mathrm{CO}_{2}$ fraction generated by decomposition of organic materials in the upper sediments, and the other is atmospheric $\mathrm{CO}_{2}$ that dissolves in the lake water.

5. Seasonal changes in the DIC $\Delta^{14} \mathrm{C}$ depth profiles were not clear, owing to a wide scatter of data points. However, we found a weak trend wherein DIC $\Delta{ }^{14} \mathrm{C}$ was higher for the bottom DIC than for the surface DIC when the water column was stratified.

\section{ACKNOWLEDGMENTS}

We would like to thank crew members of the research ship Hakken-go of the Lake Biwa Institute, Shiga Prefecture, for their help during sampling. We are also grateful to Prof. W. G. Mook of the Centre for Isotope Research, Groningen University, the Netherlands and Dr. Brian Chisholm of the University of British Columbia, Canada, for fruitful discussion in preparing the manuscript. This research was supported in part by a grant from the overseas scientist-exchange program of the Japan Society for the Promotion of Science (JSPS).

\section{REFERENCES}

Endoh, S. 1986 Diagnostic study on the vertical circulation and the maintenance mechanisms of the cyclonic gyre in Lake Biwa. Japanese Geophysical Research 91C1: 869-876.

Fuji, N. 1983 Palynological study of 200-meter core samples from Lake Biwa, central Japan, I. The palaeoveg- etational and palaeoclimatic changes during the last 600,000 years. Transactions and Proceedings of the Palaeontological Society of Japan 132: 230-252.

1986 Palynological study of 200-meter core samples from Lake Biwa, central Japan, II. The palaeovegetational and palaeoclimatic changes during $\mathbf{c a}$. 
250,000-100,000 years B.P. Transactions and Proceedings of the Palaeontological Society of Japan 144: 490-515.

Horie, S. 1984 Lake Biwa. Dordrecht, Dr. W. Junk Publishing Company: $654 \mathrm{p}$.

Keeling, C. D. 1958 The concentration and isotopic abundance of atmospheric carbon dioxide in rural areas. Geochimica et Cosmochimica Acta 13: 322-334.

Kitagawa, H., Masuzawa, T., Nakamura, T. and Matsumoto, E. 1993 A batch preparation method for graphite targets with low background for AMS ${ }^{14} \mathrm{C}$ measurements. Radiocarbon 35(2): 295-300.

Meyers, P. A., Takemura, K. and Horie, S. 1993 Reinterpretation of Late Quaternary sediment chronology of Lake Biwa, Japan, from correlation with marine glacial-interglacial cycles. Quaternary Research 39: 154-162.

Mizutani, Y., Seo, T., Ohta, K., Nakai, N. and Murai, Y. 1992 Carbon-14 ages of deep ground water from the Tono uranium mine, Gifu, Japan. In Proceedings of a Symposium on Interdisciplinary Applications of Accelerator Mass Spectrometry and Carbon Stable Isotope. Nagoya University, 28-29 November 1991: 159-168 (in Japanese with English abstract).

Mizutani, Y. and Yamamoto, K. 1993 Sources of dissolved carbonates in the shallow groundwater of the Tonami plain, Toyama. Journal of Groundwater Hydrology 35: 77-86 (in Japanese with English abstract).

Nakai, N. 1973 Carbon isotopic composition of Lake Biwa-ko sediments and the environmental change in the depositional history. Japanese Journal of Limnology 34: 89-96.

1986a Paleoenvironmental features of Lake Biwa deduced from carbon isotope compositions and organic $\mathrm{C} / \mathrm{N}$ ratios of the upper 800 -m sample of 1,400 - $\mathrm{m}$ cored column. Proceedings of Japan Academy 62B: 279-282.

1986b Temperature fluctuation and glacial ages during Brunhes Epoch deduced from carbon isotope studies of upper $250-\mathrm{m}$ sediments in $1,400 \mathrm{~m}$ Lake Biwa cored column. Proceedings of Japan Academy 62B: 283-286.

Nakamura, T., Nakai, N., Kimura, M., Kojima, S. and Maeda, H. 1986 Geological studies on radionuclides distributed in the bottom sediments of Lake Biwa. Journal of the Sedimentological Society of Japan 25: 1-14 (in Japanese with English abstract).

Nakamura, T., Nakai, N. and Ohishi, S. 1987 Applications of environmental ${ }^{14} \mathrm{C}$ measured by $\mathrm{AMS}$ as a carbon tracer. Nuclear Instruments and Methods in Physics Research B29: 355-360.

Nakamura, T., Nakai, N., Sakase., T., Kimura, M., Ohishi, S., Taniguchi, M. and Yoshioka, S. 1985 Direct detection of radiocarbon using accelerator techniques and its application to age measurement. Japanese Journal of Applied Physics 24: 1716-1723.

Nakamura, T., Nakazawa, T., Nakai, N., Kitagawa, H., Honda, H., Itoh, T., Machida, T. and Matsumoto, E. 1992 Measurement of ${ }^{14} \mathrm{C}$ concentrations of stratospheric $\mathrm{CO}_{2}$ by accelerator mass spectrometry. In Long, A. and Kra, R. S., eds., Proceedings of the 14th International ${ }^{14} \mathrm{C}$ Conference. Radiocarbon 34(3): 745-752.

Nakamura, T., Ohishi, S. and Nakai, N. 1993 Analysis of human activities and radiometric dating of bottom sediments from Horokayan-to Lake in Tokachi, Hokkaido. Chikyu Monthly 8: 138-145 (in Japanese).

Stuiver, M. and Polach, H. A. 1977 Discussion: Reporting of ${ }^{14} \mathrm{C}$ data. Radiocarbon 19(3): 355-363. 